\title{
UPAYA MENINGKATKAN PRESTASI PTK PAUD DAN DIKMAS MELALUI PEMBIMBINGAN STRATEGI AHOK DI LINGKUNGAN UPT DINAS PENDIDIKAN KECAMATAN SANGKAPURA
}

\author{
Sahrani Nur \\ Dinas Pendidikan Kecamatan Sangkapura, Gresik \\ sahranisangkapura@gmail.com
}

\begin{abstract}
ABSTRAK
Penelitian ini bertujuan untuk mendeskripsikan teknik pembimbingan yang efektif melalui Upaya Meningkatkan Prestasi PTK PAUD dan DIKMAS Melalui Pembimbingan Strategi AHOK (Aplikasi Hibrid Online Kelembagaan) dalam pengendalian mutu program PAUDNI. Mendeskripsikan kendala yang dihadapi dalam mengimplementasikan Upaya Meningkatkan Prestasi PTK PAUD dan DIKMAS Melalui Pembimbingan Strategi AHOK (Aplikasi Hibrid Online Kelembagaan)dalam pengendalian mutu program PAUDNI.

Pelaksanaan pembinaan dan pembimbingan dilaksanakan setelah adanya fakta dan data berdasarkan hasil pemantauan dan penilaian oleh penilik di wilayah kerjanya. Dengan demikian untuk melaksanakan pembimbingan harus didasarkan data hasil pemantauan dan penilaian program. Strategi pendekatan PAUD dan DIKMAS yaitu pengembangan kemampuan, dimana suatu upaya meningkatkan kemampuan lembaga secara berkelanjutan, kompetensi dan kemampuan memecahkan masalah dengan sistematis dengan tujuan Memberdayakan lembaga agar mampu mengubah sistem secara online, Menumbuh kembangkan potensipotensi lembaga yang pada akhirnya dapat diwujudkan dalam tindakan kolektif dalam peningkatan mutu pendidikan, Meningkatkan kemanpuan lembaga berbasis TIK melalui Online, dan Mewujudkan potensi-potensi PTK melalui penciptaan kreatifitas berbasis TIK melalui online karena sejalan dengan semakin canggihnya teknologi untuk menyebarkan gagasan dan informasi untuk dapat saling belajar, serta untuk mengintegrasikan pengalaman.
\end{abstract}

Katakunci : AHOC, Peningkatan Prestasi PTK, Supervisi

\section{ABSTRACT}

This study aims to describe effective coaching techniques through efforts to improve the achievement of PTK PAUD and DIKMAS through AHOK Strategy Guidance (Online Institutional Hybrid Application) in the quality control of the PAUDNI program. Describe the obstacles faced in implementing the Efforts to Improve the Achievement of PTK PAUD and DIKMAS Through AHOK Strategy Guidance (Online Institutional Hybrid Application) in the quality control of the PAUDNI program.

The guidance and guidance implementation is carried out after the facts and data are based on the results of monitoring and evaluation by the supervisor in his working area. Thus, to carry out coaching, it must be based on data from program monitoring and evaluation results. Strategies for PAUD and DIKMAS approaches, namely capacity building, in which an effort to improve the ability of institutions in a sustainable manner, competence and ability to solve problems systematically with the aim of Empowering institutions to be able to change systems online, Growing institutional potential which can be realized in collective action in improving the quality of education, Increasing the ability of ICT-based institutions through Online, and Realizing the potential of PTK through the creation of ICT-based creativity through online because it is in line with the increasingly sophisticated technology to disseminate ideas and information to be able to learn from each other, and to integrate experiences.

Keywords: AHOC, PTK Achievement Improvement, Supervision 


\section{PENDAHULUAN}

Pembangunan pendidikan yang berkualitas yang dilakukan baik oleh pemerintah pusat dan daerah adalah kegiatan pengendalian mutu setiap program. Pengendalian mutu merupakan kegiatan yang dilakukan secara sistematis dan berkelanjutan melalui pembimbingan guru dan tenaga kependidikan pada paud dan dikmas pendidikan nonformal dan informal dalam rangka memastikan penyelenggaraan layanan pendidikan melalui lembaga PAUDNI dapat mencapai standar yang ditetapkan.

Pengendalian mutu progam pendidikan nonformal dan informal sesuai dengan PP No. 19 tahun 2005 tentang Standar Nasional Pendidikan pada pasal 40 pengawasannya dilakukan oleh penilik. Tujuan dari pengawasan /pengendalian mutu program PAUDNI adalah memberikan Kualitas dan petunjuk hasil pembimbingan dan penilaian agar program PAUDNI sesuai dengan 8 (delapan ) standar pendidikan secara maksimal.

Tugas pokok dan fungsi Penilik dalam pengendalian mutu program sesuai dengan dengan kebijakan pemerintah antara lain mengacu berdasarkan Permenpan RB no 14 tahun 2010, peraturan bersama Mendiknas dan BKN nomor 02/III/PB/2011 dan Nomor 7 Tahun 2011 tentang petunjuk pelaksanaan jabatan fungsional penilik dan angka kreditnya, serta berdasarkan Peraturan Mendikbud RI no 38 Tahun
2013 tentang juknis Jabatan

Fungsional Penilik dan Angka kreditnya yaitu merencanakan, melaksanakan, penilaian, pembimbingan dan laporan pengendalian mutu program (Djazifah, 2008).

Kondisi itulah yang mengakibatkan mutu pelayanan yang diberikan oleh PTK lembaga kepada peserta didik menjadi rendah karena banyak kendala diantaranya banyak lembaga yang harus pembimbingan dalan satu kecamatan, jarak antar lembaga yang satu dengan lain cukup jauh, alat transportasi yang minim dalam melaksanaan pembimbingan dan waktu yang dibutuhkan dalam pembimbingan.

Upaya

Meningkatkan Prestasi PTK PAUD Dan DIKMAS Melalui Pembimbingan Strategi AHOK (Aplikasi Hibrid Online Kelembagaan) adalah solusinya.

Harapannya dapat mewujudkan 8 standar pendidikan dalam penyelengaraan program yang terdiri atas 4 standar, yaitu: 1) standar isi; 2) proses; 3) standar pendidik dan tenaga kependidikan; 4) penilaian; 5) standar sarana dan prasarana; 6) pengelolaan; 7) krlulusan; 8) pembiayaan. Pemerintah tentu selalu berupaya agar kompetensi PTK lembaga meningkat karena hal ini menjadi tuntutan yang tidak dapat diabaikan. Berbagai program dikembangkan dalam rangka menunjang kebijakan tersebut. 
Salah satu strategi peningkatan mutu lembaga yang telah diberlakukan pemerintah adalah melalui peningkatan kompetensi PTK. Upaya peningkatan mutu pendidik dimana pembinaan pendidikan Formal dan Nonformal ditangani oleh satu direktorat mengingat bahwa kondisi PTK lembaga pada saat ini masih sangat beragam, dan sebagian besar kualitasnya masih di bawah standar, maka menjadi kewajiban Penilik yang memiliki tugas sebagai pengendali mutu dan evaluasi dampak program PAUDNI untuk melakukan supervisi dan pembimbingan agar setiap PTK lembaga dapat meningkat kompetensinya sehingga mampu memberikan layanan secara maksimal.

Pembimbingan memiliki peranan penting untuk mengendalikan mutu. Peranan Penilik untuk melakukan pembimbingan agar kompetensi PTK lembaga meningkat menjadi sesuatu yang penting.

Dalam pengendalian mutu program PAUDNI gagasan penulis untuk mengefektifkan tugas penilik dalam mengendalikan mutu dan evaluasi dampak program PAUDNI. Harapan dalam pengendalian mutu program PAUDNI dapat tercapai secara maksimal maka kendala dalam pembimbingan di minimalisir

\section{Rumusan Masalah}

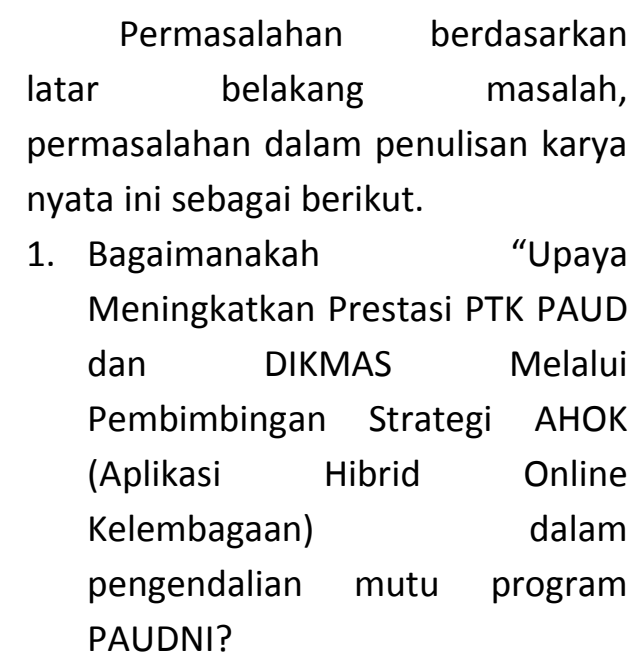

2. Apa kendala yang dihadapi dalam mengimplementasikan Upaya Meningkatkan Prestasi PTK PAUD dan DIKMAS Melalui Pembimbingan Strategi AHOK (Aplikasi Hibrid Online Kelembagaan) dalam pengendali an mutu program PAUDNI?

\section{Tujuan}

Tujuan karya tulis ilmiah ini sebagai berikut.

1. Mendeskripsikan Teknik pembimbingan yang efektif melalui "Upaya Meningkatkan Prestasi PTK PAUD Dan DIKMAS Melalui Pembimbingan Strategi AHOK (Aplikasi Hibrid Online Kelembagaan) dalam pengendalian mutu program PAUDNI?

2. Mendeskripsikan kendala yang dihadapi dalam mengimplementasikan Upaya Meningkatkan Prestasi PTK PAUD dan DIKMAS Melalui Pembimbingan Strategi AHOK 


\begin{tabular}{|c|c|}
\hline (Aplikasi & Hibrid \\
\hline Kelembagaan) & \\
\hline pengendalian & mutu \\
\hline
\end{tabular}

\section{METDOLOGI PENELITIAN}

Penelitian ini bertempat di Gugus Inti PAUD Kecamatan Sangkapura Kabupaten Gresik Tahun 2018. Penelitian ini dilangsungkan pada bulan Maret Tahun 2018.

Subyek dalam penelitian ini adalah semua Pendidik dan Tenaga Kependidikan (PTK) Gugus Inti PAUD Kecamatan Sangkapura Kabupaten Gresik Tahun 2017 yanng berjumlah 28 Orang.

\section{Rancangan Penelitian}

Penelitian ini menggunakan penelitian tindakan. Menurut pengertiannya penelitian tindakan adalah penelitian tentang hal-hal yang terjadi di masyarakat yang bersangkutan (Arikunto, 2002). Ciri atau karakteristik utama peneliti dengan penelitian tindakan adalah adanya partisipasi dan kolaborasi antara peneliti dengan anggota kelompok sasaran. Penelitian tindakan adalah satu strategi pemecahan masalah yang memanfaatkan tindakan nyata dalam bentuk proses pengembangan inovatif yang dicoba sambil jalan dalam mendeteksi dan memecahkan masalah. Dalam prosesnya pihakpihak yang terlibat dalam kegiatan tersebut dapat saling mendukung satu sama lain.
Sedangkan tujuan penelitian tindakan (Arikunto, 2002) harus memenuhi beberapa prinsip sebagai berikut:

1. Permasalahan atau topik yang dipilih harus memenuhi criteria yaitu benar-benar nyata dan penting, menarik perhatian dan mampu ditangani serta dalam jangkauan kewenangan peneliti untuk perubahan.

2. Kegiatan penelitian, baik interensi maupun pengamatan yang dilakukan tidka boleh sampai mengganggu atau menghambat kegiatan utama.

3. Jenis intervensi yang dicobakan harus efektif dan efisien artinya terpilih dengan tepat sasaran dan tidak memboroskan waktu dana dan tenaga.

4. Metodologi yang digunakan harus jelas, rinci dan terbuka, setiap langkah dan tindakan dirumuskan dengan tegas sehingga orang yang berminat terhadap penelitian tersebut dapat mengecek setiap hipotesis dan pembuktiannya.

5. Kegiatan penelitian diharapkan dapatmerupakan proses kegiatan yang berkelanjutan (on-going) mengingat bahwa pengembangan dan perbaikan terhadap kualitas tindakan memang tidak dapat berhenti tetapi menjadi tantangan sepanjang waktu.

Sesuai dengan jenis penelitian yang dipilih yaitu penelitian tindakan, maka penelitian ini menggunakan model penelitian tindakan dari 
Kemmis dan Taggart (Arikunto, 2002) berbentuk spiral dari siklus yang satu ke siklus yang berikutnya. Setiap siklus meliputi planning (rencana), action (tindakan), observasi (pengamatan), dan reflection (refleksi). Langkah pada siklus berikutnya adalah perencanaan yang sudah di revisi, tindakan, pengamatan dan refleksi. Sebelum masuk pada siklus I dilakukan tindakan pendahuluan yang berupa identifikasi permasalahan. Siklus spiral dari tahap-tahap penelitian tindakan kelas dapat dilihat pada gambar 1 berikut.

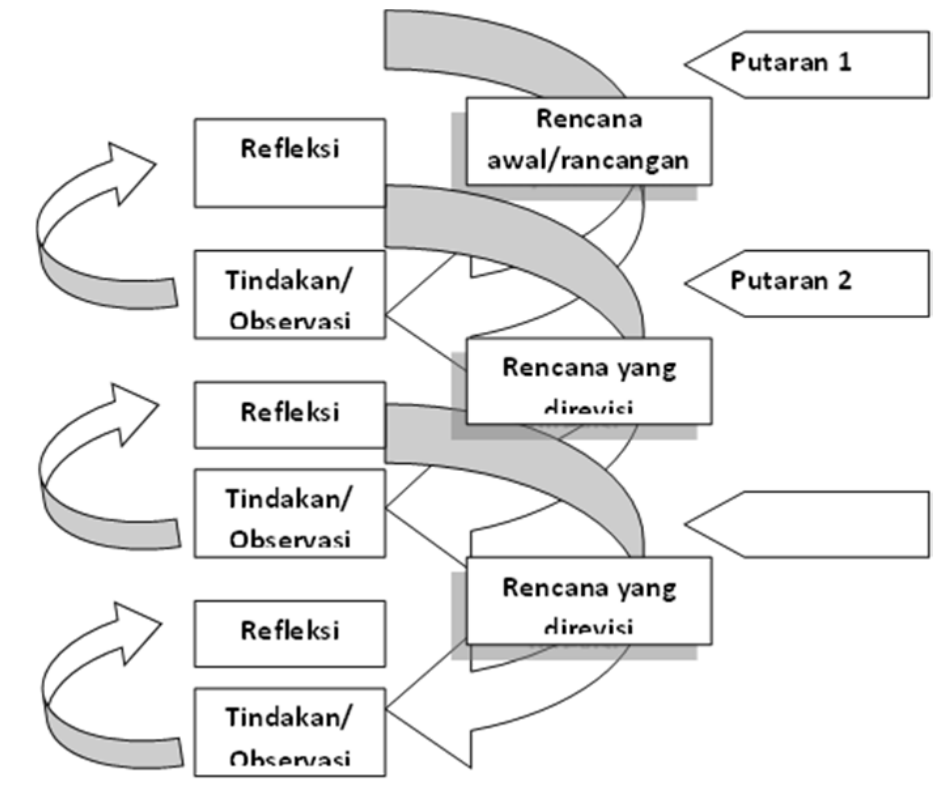

Gambar 1. tahap-tahap penelitian tindakan

Penjelasan alur di atas adalah:

1. Rancangan/rencana awal, sebelum mengadakan penelitian menyusun rumusan masalah, tujuan dan membuat rencana tindakan termasuk di dalamnya instrument penelitian dan perangkat pembelajaran.

2. Kegiatan dan pengamatan meliputi tindakan yang dilakukan oleh peniliti sebagai upaya membangun pemahaman konsep Orang serta mengamati hasil atau dampak dari diterapkannya pembelajaran kolaborasi.

3. Refleksi, peneliti mengkaji, melihat dan mempertimbangkan hasil atau dampak dari tindakan yang dilakukan berdasarkan lembar pengamatan yang diisi oleh pengamat.

4. Rancangan/rencana yang direvisi, berdasarkan hasli refleksi dari pengamat membuat rancangan yang direvisi untuk dilaksanakan pada siklus berikutnya: 
Observasi dibagi dalam tiga putaran, yaitu putaran 1,2 dan 3 dimana msing-masing putaran dikenai perlakuan yang sama (alur kegiatan yang sama) dan membahas satu sub pokok bahasan yang diakhiri dengan tes formatif di akhir masingmasing putaran. Siklus ini berkelanjutan dan akan dihentikan jika sesuai dengan kebutuhan dan dirasa sudah cukup.

\section{Alat Pengumpul Data}

Alat pengumpul data dalam penelitian ini adalah tes buatan guru yang fungsinya adalah (1) untuk menentukan seberapa baik Orang telah menguasai bahan pelajaran yang diberikan dalam waktu tertentu: (2) untuk menentukan apakah suatu tujuan telah tercapai dan (3) untuk memperoleh suatu nilai (Arikunto, 2002:149). Sedangkan tujuan dari tes adalah mengetahui ketuntasan belajar Orang secara individu maupun secara klasikal. Disamping itu untuk mengatahui letak kesalahan-kesalahan yang dilakukan Orang sehingga dapat dilihat dimana kelemahan, khususnya pada bagian mana TPK yang belum tercapai. Untuk memperkuat data yang dikumpulkan maka juga digunakan metode observasi (pengamatan) yang dilakukan oleh teman sejawat untuk mengetahui dan merekam aktivitas guru dan Orang dalam proses belajar mengajar.

\section{Analisis Data}

Dalam rangka menyusun dan mengelola data yang terkumpul sehingga dapat menghasilkan suatu kesimpulan yang dapat dipertanggungjawabkan maka digunakan analisis dan kuantitatif dan pada metode observasi digunakan data kuantitatif. Cara perhitungan untuk mengetahui ketuntasan belajar Orang dalam proses belajar mengajar sebagai berikut:

1. Merekapitulasi hasil tes

2. Merekapitulasi hasil pengamatan

3. Menghitung jumlah skor yang tercapai dan prosentasenya untuk masing-masing Orang dapat menggunakan rumus ketuntasan belajar seperti yang terdapat dalam buku petunjuk teknis penilaian Orang dikatakan tuntas secara individual jika mendapatkan nilai minimalh 65, sedangkan secara individual mencapau $85 \%$ yang telah mencapai daya serap lebih dari sama dengan $65 \%$.

Untuk mengetahui keefektifan suatu metode dalam kegiatan pembelajaran perlu diadakan analisis data. Pada penelitian ini menggunakan teknik analisis dekriptif kualitataif, yaitu suatu metode penelitian yang bersifat menggambarkan kenyataan atau fakta sesuai dengan data yang diperoleh dengan tujuan untuk mengetahui prestasi belajar yang 
dicapai Orang, juga untuk memperoleh respon Orang terhadap kegiatan pembelajaran serta aktivitas Orang selama proses pembelajaran.

Untuk menganalisis tingkat keberhasilan atau prosentase keberhasilan Orang setelah proses belajar mengajar setiap putarannya dilakukan dengan cara memberikan evaluasi berupa soal tes tertulis pada setiap akhir putaran.

Analisis ini dihitung dengan menggunakan statistika sederhana yaitu:

1. Untuk menilai ulangan atau tes formatif

Peneliti melakukan penjumlahan nilai yang diperoleh Orang, yang selanjutnya dibagi dengan jumlah Orang yang ada di kelas tersebut sehingga diperoleh rata-rata tes formatif dapat dirumuskan:

$$
\text { Dengan } \begin{aligned}
& \bar{X}=\frac{\sum x}{\sum N} \\
& \bar{X}=\text { Nilai rata-rata } \\
& \Sigma \mathrm{X}=\text { Jumlah semua } \\
& \Sigma \mathrm{N}=\text { nilai Orang } \\
& \text { Banyak Orang }
\end{aligned}
$$

2. Untuk ketuntasan belajar

Ada dua kategori ketuntasan belajar yaitu secara perorangan dan secara klasikal. Berdasarkan pelaksanaan belajar mengajar kurikulum 2006 (Depdikbud, 2006), yaitu seorang Orang telah tuntas belajar bila telah mencapai skor $65 \%$ atau nilai 65 , dan kelas disebut tuntas belajar baik di kelas tersebut terdapat $85 \%$ yang telah mencapai daya serap lebih dari atau sama dengan 65\%. Untuk menghitung prosentase ketuntasan belajar digunakan rumus sebagai berikut:

$$
P=\frac{\text { Orang yang tuntas belajar }}{\text { Orang }} \times 100 \%
$$

3. Untuk lembar observasi Untuk menghitung lembar observasi pengelolaan metode pembelajaran kooperatif Team Games Tournament digunakan rumus sebagai berikut:

$$
\bar{X}=\frac{P 1+P 2}{2}
$$

Dimana: $P 1=$ Pengamat 1 $\mathrm{P} 2$ = Pengamat 2

Untuk menghitung lembar observasi aktivitas guru dan siswa digunakan rumus sebagai berikut:

$$
\%=\frac{\bar{x}}{\sum x} \times 100 \%
$$

dengan

$$
\bar{X}=\frac{\text { Jumlah hasil pengamatan }}{\text { Jumlah pengamatan }}=\frac{P 1+P 2}{2}
$$

Dimana :

$$
\%=\text { Prosentase Pengamatan }
$$

$\bar{X}=$ Rata-rata

$\Sigma \mathrm{X}=$ Jumah rata-rata

$\mathrm{P} 1$ = Pengamat 1

$\mathrm{P} 2$ = Pengamat 2

\section{HASIL DAN PEMBAHASAN}

\section{Hasil Penelitian}

Karya nyata ilmiah ini menggunakan analitis deskriptif yang ada di PAUD dan Wilayah UPT Dinas 
Pendidikan Kecamatan Sangkapura

Kabupaten Gresik yang efektif dalam permasalahan pembimbingan dan penulisan menggambarkan Implementasi di PAUD dan DIKMAS. Meliputi :

\section{Perencanaan}

program pengendalian mutu

Program pengendalian mutu dituangkan dalam rencana kerja tahunan dan rencana triwulan.

\section{Rancangan}

pembimbingan

pelaksanaan

(Aplikasi Hibrid Online Kelembagaan)

Pembimbingan dilaksanakan melalui supervisi manajerial dan supervisi akademik dengan sasaran pada pengelola dan tenaga pendidik lembaga penyelenggara Pendidikan Non Formal, baik mengenai kelembagaan maupun pelaksanaan programnya sehingga diperoleh data yang diperlukan sebagai bahan pertimbangan untuk melaksanakan pembimbingan. Proses pelaksanaan pembimbingan dilakukan melalui tahap tertuang dalam gambar rencangan pelaksanaan pembimbingan melalui cara AHOK.

\section{a. Perencanaan}

Yaitu

proses

merancangan/menyusun

perencanaan program

pembimbingan sesuai dengan sasaran, meliputi persiapan penyediaan kelengkapan instrument pendataan, persiapan aplikasi software dan pembuatan jadwal pelaksanaan.

\section{b. Pengorganisasian}

Sebelum kegiatan pembimbingan dilaksanakan melalui cara AHOK, terlebih dahulu diadakan pertemuan dengan pengelola satuan lembaga Pendidikan Non Formaldalam rangka mensosialisasikanrencana kegia tan evaluasi program. Selanjutnya Jadwal pelaksanaan pembimbingan yang telah dibuat disampaikan kepada pengelola

\section{c. Pelaksanaan}

Pelaksanaan

pembimbingan di masing masing lembaga dilaksanakan sesuai dengan substansi pembimbingan adalah supervisi manajerial yaitu Standar pengelolaan, dengan sasaran PTK satuan PAUDNI. Hasil pembimbingan dianalisa dan didapatkan data sasaran dari masing-masing pengelola satuan PAUDNI, Data yang diperoleh dari hasil pembimbingan kemudian dituangkan dalam bentuk tabulasi data. 


\section{d. Melaksanakan Pembimbingan}

Pembinaan diberikan secara individu maupun kelompok kepada Tenaga Pendidik Dan Tenaga Kependidikan meliputi :

1) Penyusunan perencanaan Mengajar

2) Metode dan strategi pembelajaran

3) Teknik penilaian / evaluasi pembelajaran

4) Tenaga Kependidikan (Pengelola/Penyelenggara) mengenai manajemen pendidikan non formal, mengacu pada pemenuhan 8 (delapan) standar pendidikan nasional

\section{e. Melaksanakan penilaian}

Penilaian dilakukan dalam rangka mengetahui perkembangan pelaksanaan program PAUDNI yang ada di wilayah binaan masing-masing, melalui tahapan Membuat instrumen penilaian / evaluasi Kinerja pendidik dan tenaga kependidikan, Kinerja satuan pendidikan non formal, dan Dampak pelaksanaan program

\section{f. Teknik pengumpulan data.}

Teknik pengumpulan data diperoleh melalui pengembangan berbasis TIK (teknologi Informasi dan Komunikasi) Online :
1) Observasi dilakukan untuk mengetahui perencanaan, Pendataan, Pemantauan/ pelaksanaan dan evaluasi wilayah binaan masingmasing

2) Penggumpulan dokumentasi dilakukan untuk mengetahui gambaran berupa berkas administrasi PTK, foto-foto kegiatan dengan Upload dalam sistem Online.

3) Pendataan lembaga, Instrumen, penilaian dan pembimbingan hasil berupa data dapat diisi secara Online.

\section{g. Teknik Pemecahan Masalah}

Alasan Pemilihan teknik pembimbingan yang efektif melalui cara AHOK sebagai Pemecahan Masalah antara lain.

1) Jangkauan antar lembaga denganlainnya terlalu jauh terutama di daerah daerah terpencil.

2) Jumlah PTK yang sangat banyak .

3) Efektif menghemat waktu dan biaya

4) Proses cepat melalui Basis Teknologi Informasi dan Komunikasi (TIK) melalui cara AHOK.

5) Dapat diisi langsung dan lampiran dokumen di Upload 
6) Dapat dilihat hasil pendataan, pemantauan, penilaian dan pembimbingan dari tabulasi data secara langsung.

Mekanisme pembimbingan berbasis TIK melalui cara AHOK dalam pengendalian mutu program PAUDNI berikut ini.

1) Perencanaan

- Perencanaan pertama dilakukan dengan mempersiapkan indikator dan membuat instrumen sesuai dengan 8 standar pendidikan.

- Perencanaan kedua dengan membuat software berbasis TIK melalui cara AHOK

- Perancangan jadwal kegiatan dalam pembimbingan lembaga.

- Pemberian registrasi software dan Password pada lembaga User ID dengan menuliskan nama lembaga dan Password yang berbeda setiap lembaga.

2) Pengorganisasian

- Sosialisasi penggunaan software kepada lembaga dan penilik dan instansi terkait mengenai rancangan berbasis TIK melalui cara AHOK.
- Sosialisasi tupoksi penilik tentang pengendalian mutu dan evaluasi dampak program PAUDNI kepada para penilik dan lembaga kesetaraan dan keaksaraan, pendidikan anak usia dini dan kursuskursus / LKP. Perhatikan gambar model aplikasi cara AHOK.

3) Pelaksanaan kegiatan Pelaksanaan kegiatan pembimbingan sesuai jadwal yang dirancang dimana lembaga mengisi "ya" artinya ada dan "tidak" artinya tidak ada. Untuk bukti fisik pernyataanya lembaga mengunggah Dokumentasi atau administrasi pada sistem aplikasi cara AHOK tersebut.

4) Data Penilaian

Data penilaian berupa Tabulasi yang terintergrasi dalam sistem Online. Dari pernyataan dan jawaban ya dan tidak. Bila ya skor 1 jika lengkap dan ya 0,5 jika tidak lengkap dan score 0 jika jawaban pernyataan tidak, Berdasarkan Skala likert. Contoh model tabulasi pada gambar tabel contoh data tabulasi penilaian cara AHOK. 


\begin{tabular}{|c|c|c|c|c|c|c|c|c|c|c|}
\hline No & $\begin{array}{c}\text { Nama } \\
\text { Lembaga }\end{array}$ & Isi & $\begin{array}{c}\text { Pro } \\
\text { ses }\end{array}$ & SKL & PTK & Sapras & $\begin{array}{c}\text { P. } \\
\text { Lola }\end{array}$ & $\begin{array}{c}\text { P } \\
\text { Biaya }\end{array}$ & $\begin{array}{c}\text { P } \\
\text { Nilai }\end{array}$ & Score \\
\hline 1 & 2 & 3 & 4 & 5 & 6 & 7 & 8 & 9 & 10 & 11 \\
\hline & & & & & & & & & & \\
\hline \multicolumn{2}{|l|}{ Rata2 Score } & & & & & & & & & \\
\hline
\end{tabular}

Gambar 6. Model data tabulasi penilaian cara AHOK

Contoh Persentase Tabulasi dari data penilaian dapat dilihat pada gambar tabel sebagai berikut :

\begin{tabular}{|c|c|c|c|c|c|c|c|c|c|c|}
\hline No & $\begin{array}{c}\text { Nama } \\
\text { Lembaga }\end{array}$ & $\begin{array}{c}\% \\
\text { Isi }\end{array}$ & $\begin{array}{c}\% \\
\text { Proses }\end{array}$ & $\begin{array}{c}\% \\
\text { SKL }\end{array}$ & $\begin{array}{c}\% \\
\text { PTK }\end{array}$ & $\begin{array}{c}\% \\
\text { Sapras }\end{array}$ & $\begin{array}{c}\% \\
\text { lola }\end{array}$ & $\begin{array}{c}\% \\
\text { Biaya }\end{array}$ & $\begin{array}{c}\% \\
\text { Nilai }\end{array}$ & $\begin{array}{c}\% \\
\text { Score }\end{array}$ \\
\hline 1 & 2 & $\mathbf{3}$ & $\mathbf{4}$ & $\mathbf{5}$ & $\mathbf{6}$ & $\mathbf{7}$ & $\mathbf{8}$ & $\mathbf{9}$ & $\mathbf{1 0}$ & 11 \\
\hline & & & & & & & & & & \\
\hline & & & & & & & & & & \\
\hline \multicolumn{2}{|l}{ Rata Score \% } & & & & & & & & & \\
\hline
\end{tabular}

Gambar 7. Model data tabulasi persentasi penilaian online

Data dapat berupa pula berupa diagram seperti pada contoh dalam gambar tabel sebagai berikut:

5) Pembingan lembaga setelah diadakan penilaian

Pelaksanaan

pembinaan dan pembimbingan kepada PTK oleh penilik merupakan langkah yang sangat tepat dalam tahapan kegiatan kepenilikan sebelumnya, yaitu pelaksanaan pemantauan program dan pelaksanaan penilaian program. Artinya pelaksanaan pembinaan dan pembimbingan dilaksanakan setelah adanya fakta dan data berdasarkan hasil pemantauan dan penilaian oleh penilik diwilayah kerjanya. Dengan demikian untuk melaksanakan pembimbingan harus didasarkan data hasil pemantauan dan penilaian program.

\section{Pelaksanaan}

pembimbingan dan pembinaan oleh penilik dilakukan kepada pendidik dan tenaga kependidikan pada satuan pendidikan nonformal. Berdasarkan rincian butir kegiatan penilik, maka pelaksanaan pembimbingan dan pembinaan meliputi:

1) Pembimbingan dan pembinaan kepada pendidik dan tenaga kependidikan 

berdasarkan standar pendidikan.

2) Pembimbingan dan pembinaan kepada pendidik dan tenaga kependidikan dalam melakukan penelitian atau pengembangan pembelajaran, pelatihan, dan pembimbingan.

3) Pembimbingan dan pembinaan kepada pendidik dan tenaga kependidikan dalam menggunakan dan mengembangkan media pembelajaran dan teknologi informasi untuk kegiatan pembalajaran, pelatihan, dan bimbingan.

Pada tahapan ini penilik melalukan pembinaan dan bimbingan PTK berdasarkan pemantan Sebagai contoh hasil temuan pada pemetaan pembinaan dan pembimbingan PTK berikut ini.

1) Tutor belum menggunakan model pembelajaran yang inovatif.

2) Tutor tidak menggunakan media pembelajaran yang menarik.

3) Lembaga belum memiliki alat pembelajaran yang lengkap

4) Pendidik belum bisa menyusun silabus, RPP dan membuat Kisi-kisi dalam penilaian serta bedah SKL dan sebagainya.
5) Tenaga Adminstrasi belum maksimal di berdayakan karena faktor sumber daya manusia yang belum memiliki kompetensi khusus.

Adapun langkah pelaksanaan pembinaan dan pembimbingan melalui teknik adalah sebagai berikut.

a. Identifikasi pembinaan dan pembimbingan

Untuk mempermudah penilik, proses identifikasi dapat dilakukan dengan melihat hasil evaluasi tahun yang lalu.Selain itu,proses identifikasi dilakukan dengan melakukan kegiatan TNA (Traning Needs Analisis). Suatu kegiatan untuk mengetahui halhal apa yang dibutuhkan oleh PTK sehubungan dengan tugas pokok keseharian untuk di bahas di kegiatan pelatihan yg mengacu 8 standar pendidikan.

b. Pelaksanaan pembinaan dan pembimbingan

$$
\text { Dalam }
$$
kegiatan pelaksanaan di forum PKBM, HIMPAUDI dan HIPKI dimana untuk mengefektifkan kegiatan, pesertanya bimbingan. Sebagai contoh permasalahan yang segera diatasi kaitannya dengan metode pembelajaran terutama kemampuan tutor yang rendah. Untuk memfasilitasinya Penilik bisa mencarikan nara sumber. 
c. Refleksi pembinaan dan pembimbingan

Refleksi dilakukan untuk mengetahui kekurangan dan kelebihan pelaksanaan

kegiatan.Refleksi meliputi seluruh aspek pelaksanaan. Dari materi, nara sumber, peserta, sarana, dan prasarana, tugas yang harus dikumpulkan, efektifitas kegiatan dll. Hal yang kurang, diperbaiki secara terus menerus kekuatannya dipertahankan sekaligus ditingkatkan.

\section{Pembahasan}

Bagi penyelenggara pendidikan ada kendala-kendala yang dihadapi sehubungan dengan masalah tersebut di atas yaitu:

1. Kurangnya sarana pendukung berbasis TIK melalui Online

2. Kurangnya kuatnya / lemah sinyal jaringan di daerah yang sangat terpencil.

3. Kurangnya sumber daya manusia tentang pemahaman teknologi informasi ddan komunikasi melalui online.

4. Tidak menetapnya tenaga PTK di PKBM.

5. Tugas penanggungjawab PKBM yang bertumpuk-tumpuk'

6. Mengaktifkan dan mengefektifkan Forum PKBM utuk mengadakan diklat, seminar, works shop tentang materi maupun metodologi pengajaran
Hal itulah yang menyebabkan rendahnya mutu pendidikan yang menghambat penyediaan sumber daya menusia yang mempunyai keahlian dan keterampilan untuk memenuhi pembangunan bangsa di berbagai bidang. Penyebab rendahnya mutu pendidikan di Indonesia antara lain adalah masalah efektifitas, efisiensi dan standardisasi pengajaran. Hal tersebut masih menjadi masalah pendidikan di Indonesia pada umumnya.

\section{Faktor Pendukung}

Dengan dasar melihat peta kekuatan atau pendukung organisasi yang menunjukkan bahwa PAUD dan DIKMAS dalam situasi yang sangat menguntungkan tersebut memiliki peluang dan kekuatan sehingga dapat memanfaatkan peluang yang ada. Strategi yang harus diterapkan dalam kondisi ini adalah mendukung kebijakan pertumbuhan yang agresif (Growth oriented strategy). Ada faktor pendorong kekukatan dan peluang antara lain :
a. Sebagai
pendukung pembimbingan yang efektif dalam pengendalian mutu program PAUDNI.
b. Sebagai pendukung pendidikan Formal
c. Pelaksanaan flaksibel.
d. Lembaga memiliki mitra yang sangat banyak.
e. Tenaga Volunter tersedia untuk membantu sebagai pendidik.


Oleh karena itu perlu teknik yang digunakan dalam melakukan pembimbingan terhadap PTK yang mencakup proses pembelajaran atau pengelolaan program PAUD dan DIKMAS berdasarkan indikator keberhasilan yang ditetapkan.

\section{Alternatif Pengembangan}

Strategi pendekatan PAUD dan DIKMAS yaitu pengembangan kemampuan, dimana suatu upaya meningkatkan kemampuan lembaga secara berkelanjutan, kompetensi dan kemampuan memecahkan masalah dengan sistematis dengan tujuan :

a. Memberdayakan lembaga agar mampu mengubah sistem secara online.

b. Menumbuh kembangkan potensipotensi lembaga yang pada akhirnya dapat diwujudkan dalam tindakan kolektif dalam peningkatan mutu pendidikan

c. Meningkatksn kemanpuan lembaga berbasis TIK melalui Online,

d. Mewujudkan potensi-potensi PTK melalui penciptaan kreatifitas berbasis TIK melalui online.

Strategi pendekatan pembentukan jaringan Online dan kemitraan yang sejalan dengan semakin canggihnya teknologi untuk menyebarkan gagasan dan informasi untuk dapat saling belajar, serta untuk mengintegrasikan pengalaman.

\section{PENUTUP}

\section{Kesimpulan}

Kegiatan pembimbingan yang efektif berbasis TIK melalui Aplikasi Hibrid Online Kelembagaan (AHOK) yang dapat dijadikan acuan, rujukan, pemecahan masalah, peningkatan mutu program PAUDNI.

1. Pendekatan pengembangan berbasis TIK melalui Online dirancang untuk memberdayakan lembaga yang mampu mewujudkan eksistensi secara mandiri dan kolektif dalam pengendalian mutu program PAUDNI.

2. Teknik pembimbingan yang efektif berbasis TIK melalui Online dalam pengendalian mutu program PAUDNI perlu adanya rancangan pendekatan pembentukan jaringan dan kemitraan yang sejalan dengan semakin canggihnya teknologi untuk menyebarkan gagasan dan informasi.

\section{Rekomendasi}

Berdasarkan pembimbingan yang dilakukan selama ini di PAUD dan DIKMAS kurang efektif ini penulis merekomendasikan kepada Instansi terkait dengan pendidikan Non formal dan Informal melalui Kementrian Pendidikan dan kebudayaan Republik Indonesia umumnya dan Direktur Jenderal PAUDNI agar segera membenahi hal hal sebagai berikut :

1. Pembimbingan yang dilakukan oleh penilik selama ini kurang 
efektif, kurang efesien hingga pencapaian tujuan dalam pengendalian mutu dan evaluasi dampak program PAUDNI kurang maksimal perlu dirancang dengan menggunakan teknologi informasi dan komunikasi ( TIK ) melalui Online.

2. Penggunaan teknologi Informasi dan komunikasi ( TIK ) melalui cara AHOK sangat membantu dalam tugas Penilik dalam pendataan, pemantauan, penilaian, pemetaan dalam pembinaan dan bimbingan terhadap PTK dalam pengendalian mutu dan evaluasi program PAUDNI.

3. Faktor kelemahan PTK PAUDNI. Kebanyakan PTK belum memiliki profesionalisme yang memadai untuk menjalankan tugas sebagai penentu keberhasilan oleh karena itu perlu mengadakan bimtek, diklat, seminar, works shop tentang materi, metodologi pengajaran, teknik penilaian, diklat adminstrasi lembaga dan diklat managemen pengelola dan diklat lain yang mendukung program lembaga.

\section{DAFTAR PUSTAKA}

Arikunto, Suharsimi, 2002. Prosedur Penelitian Suatu Pendekatan Praktek. Jakarta. PT. Rineka Cipta

Dimyati dan Mujiono. 2009. Belajar dan Pembelajaran. Jakarta : Rineka Cipta
Djazifah, Nur ER, dkk. 2008. Pemetaan tingkat Pencapaian Mutu Pendidikan pada Pusat Kegiatan Belajar Masyarakat (PKBM) Laporan penelitian kelompok, Yogyakarta: Jurusan PLS FIP UNY.

Heinich, R.M Russel, J.D dan Smaldino, S.E. 1996. Instructional Media and Technology for Learning. New York: Mac Milan Publishing Company

Karyadi, Benny. 2005. Pembelajaran dengan menggunakan Komputer dalam proses pembetukan Manusia yang berdaya. Jakarta: Work Shop Pesona Matematika

Romli, Asep Syamsu M. 2013. jurnalistik panduan online. Jakarta : Rineka Cipta

Sudjana, Djuju. 2010. Manajemen Program Pendidikan untuk Pendidikan Luar Sekolah dan Pengembangan Sumber Daya Manusia. Bandung: Fallah Production.

Suryono, Yoyon. 2007. Peningkatan Kemampuan Pusat Kegiatan Belajar Masyarakat (PKBM). Yogyakarta: UNY Press

Zainuddin, Arif. 2003. Pengelolaan dan Pemberdayaan Pusat Kegiatan Belajar Masyarakat. 